\title{
HOMENAGEM AO PROFESSOR LUÍS EULÁLIO DE BUENO VIDIGAL
}

Professor universitário e industrial. Nasceu em São Paulo, em 4 de fevereiro de 1911. Filho de Gastão Vidigal e Maria Amélia de Bueno Vidigal. Fez o curso primário no Ginásio de Nossa Senhora do Carmo; o secundário no Ginásio do Estado da Capital e o superior na Faculdade de Direito da Universidade de São Paulo. Bacharel em Ciências e Letras; bacharel em Ciências Jurídicas e Sociais; Doutor em Direito; Técnico de Administração. Foi advogado militante; consultor jurídico da Associação dos Bancos de São Paulo; professor catedrático de Direito Judiciário Civil da Universidade de São Paulo; ao aposentar-se, a Congregação dessa Faculdade conferiu-lhe o título de Professor Emérito. Foi presidente da Cobrasma S.A. e Fornasa S.A., e membro do Conselho de Administração da Confab Industrial S.A. Conquistou o Prêmio Antonio de Godoy, anualmente conferido ao aluno do Ginásio do Estado da Capital que tenha, em todo o curso, obtido as melhores notas; foi, por escolha de seus colegas, orador da turma de 1932 da Faculdade de Direito da Universidade de São Paulo; recebeu, em 1942, o Prêmio Instituto dos Advogados de São Paulo (trabalhos jurídicos). Foi em 1941 e 1942 e em 1951 e 1952 do Conselho da Ordem dos Advogados do Brasil. Foi paraninfo dos bacharelandos da Faculdade de Direito da Universidade de São Paulo das turmas de 1960, 1963 e 1966. Foi diretor da Faculdade de Direito da Universidade de São Paulo no período de 1963/1966. Como diretor da Faculdade de Direito exerceu o cargo de Reitor da Universidade de São Paulo. Foi-lhe outorgada, em 1985, a láurea corporificada na "Medalha João Mangabeira" pela contribuição científica dada ao estudo de madado de segurança.

Livros publicados: Da Ação Rescisória dos Julgados; Da Execução Direta das Obrigações de Prestar Declaração de Vontade; Direito Processual Civil; Do Mandado de Segurança; Comentários ao Código de Processo Civil de 1973 (artigos 485 e 495) editado pela Editora Revista dos Tribunais. Outros trabalhos: A Federação e a Constitucionalização do País, (1932); Sindicalização de empregadores, (1940); Do Mandado de Segurança, (na Coleção de Estudos em honra de F Carnelutti); Escopo do Processo Civil; Existe o Direito de Ação? Conexão de Causas; Execução de sentença na pendência dos recursos de revista e extraordinário; O processo civil e a reforma constitucional; Francisco Campos e a Constituição de 1937; Os professores de processo civil da Faculdade de Direito; Prechè unificare il Diritto Processuale (na coletânea de estudos em honra de 
Enrico Tullio Liebman, 1978). Incumbiu-se da redação de vários verbetes na Enciclopédia Saraiva de Direito. Incumbiu-se da redação de vários verbetes no Digesto de Processo editado pela Universidade Federal de Uberlândia, MG; Discursos Universitários.

O professor Luís Eulálio do Bueno Vidigal faleceu em 15 de novembro de 1995 . 


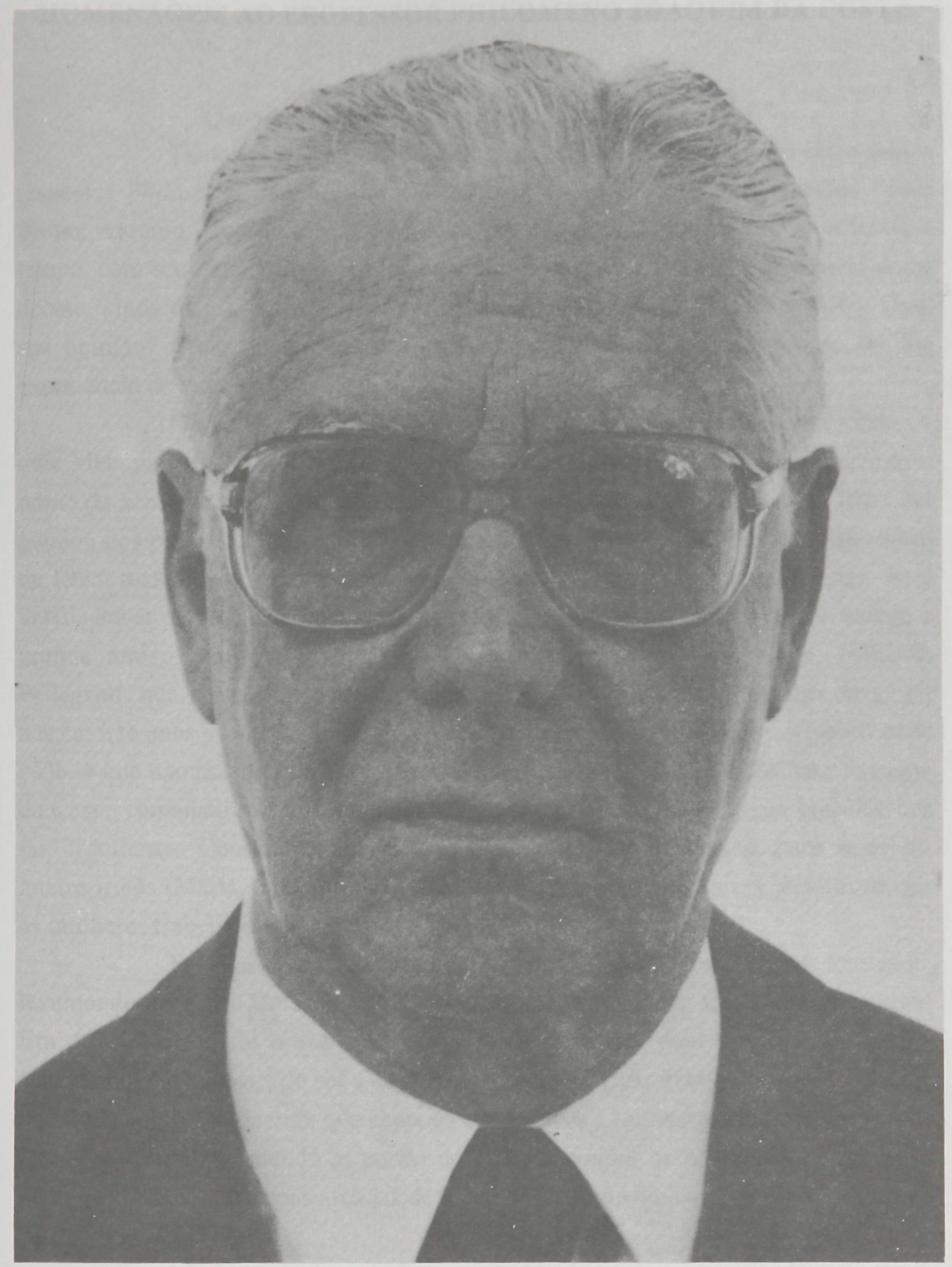

Professor Luís Eulálio de Bueno Vidigal 